\title{
ESTIMATING VERTEX-DEGREE-BASED ENERGIES
}

Ivan Gutman

University of Kragujevac, Faculty of Science,

Kragujevac, Republic of Serbia,

e-mail: gutman@kg.ac.rs,

ORCID iD: (Dhttps://orcid.org/0000-0001-9681-1550

DOI: 10.5937/vojtehg70-35584;https://doi.org/10.5937/vojtehg70-35584

FIELD: Mathematics

ARTICLE TYPE: Original scientific paper

Abstract:

Introduction/purpose: In the current literature, several dozens of vertexdegree-based (VDB) graph invariants are being studied. To each such invariant, a matrix can be associated. The VDB energy is the energy (= sum of the absolute values of the eigenvalues) of the respective VDB matrix. The paper examines some general properties of the VDB energy of bipartite graphs.

Results: Estimates (lower and upper bounds) are established for the VDB energy of bipartite graphs in which there are no cycles of size divisible by 4 , in terms of ordinary graph energy.

Conclusion: The results of the paper contribute to the spectral theory of VDB matrices, especially to the general theory of VDB energy.

Keywords: vertex-degree-based graph invariant, vertex-degree-based matrix, vertex-degree-based energy, energy (of graph).

\section{Introduction}

Let $G$ be a simple graph with the vertex set $\mathbf{V}(G)$ and the edge set $\mathbf{E}(G)$.

If the vertices $u, v \in \mathbf{V}(G)$ are adjacent, then the edge connecting them is denoted by $u v$. The number of edges incident to a vertex $v$ is the degree of that vertex, and is denoted by $d(v)$. The minimum and maximum vertex degrees are denoted by $\delta$ and $\Delta$, respectively.

Let $\mathbf{V}(G)=\left\{v_{1}, v_{2}, \ldots, v_{n}\right\}$. Then the adjacency matrix $\mathbf{A}(G)=\left[a_{i j}\right]$ of the graph $G$ is the symmetric matrix of order $n$, whose elements are (Cvetković et al, 2010): 


$$
a_{i j}= \begin{cases}1 & \text { if } v_{i} v_{j} \in \mathbf{E}(G) \\ 0 & \text { if } v_{i} v_{j} \notin \mathbf{E}(G) \\ 0 & \text { if } i=j .\end{cases}
$$

If the eigenvalues of $\mathbf{A}(G)$ are $\lambda_{1}, \lambda_{2}, \ldots, \lambda_{n}$, then the (ordinary) energy of the graph $G$ is defined as

$$
\mathcal{E}=\mathcal{E}(G)=\sum_{i=1}^{n}\left|\lambda_{i}\right| .
$$

The theory of graph energy is nowadays elaborated in due detail ( $\mathrm{Li}$ et al, 2012; Ramane, 2020).

In the chemical and mathematical literature, a variety of vertex-degreebased (VDB) graph invariants of the form

$$
\mathcal{I}=\mathcal{I}(G)=\sum_{u v \in \mathbf{E}(G)} f(d(u), d(v))
$$

has been considered, where $f$ is a suitably chosen function, with a property $f(x, y)=f(y, x)$ (Kulli, 2020; Todeschini \& Consonni, 2009).

These are usually referred to as topological indices. Of these, we list here a few most popular and best studied ones: 


\begin{tabular}{|l|l|c|}
\hline$f(x, y)$ & name of index & type \\
\hline$x+y$ & first Zagreb & $\uparrow$ \\
$x y$ & second Zagreb & $\uparrow$ \\
$x^{2}+y^{2}$ & forgotten & $\uparrow$ \\
$\sqrt{x^{2}+y^{2}}$ & Sombor & $\uparrow$ \\
$\sqrt{x+y}$ & nirmala & $\uparrow$ \\
$1 / \sqrt{x y}$ & Randić & $\downarrow$ \\
$1 / \sqrt{x+y}$ & sum-connectivity & $\downarrow$ \\
$2 /(x+y)$ & harmonic & $\downarrow$ \\
$1 / x^{2}+1 / y^{2}$ & inverse degree & $\downarrow$ \\
$1 / \sqrt{x^{2}+y^{2}}$ & modified Sombor & $\downarrow$ \\
{$[(x+y-2) /(x y)]^{1 / 2}$} & atom-bond-connectivity & $\sim$ \\
$|x-y|$ & Albertson & $\sim$ \\
\hline
\end{tabular}

The parameters $x$ and $y$ (being vertex degrees) always satisfy the condition $x \geq 1, y \geq 1$. Bearing this in mind, we immediately recognize that most VDB indices are either monotonically increasing $(\uparrow)$ or monotonically decreasing functions $(\downarrow)$ of the vertex degrees. Only a few such indices do not possess such a monotonicity property $(\sim)$.

It should be noted that for practically all VDB indices of type $\uparrow$ that exist in the literature, the condition $f(x, y) \geq 1$ is satisfied for all values of $x$ and $y$ that occur for the edges of graphs. Analogously, for practically all VDB indices of type $\downarrow, 0<f(x, y) \leq 1$ holds for all values of $x$ and $y$.

Taking into account Eqs. (1) and (3), we introduce the VDB matrix $\mathbf{A}_{\mathcal{I}}(G)=\left[\left(a_{\mathcal{I}}\right)_{i j}\right]$ via

$$
\left(a_{\mathcal{I}}\right)_{i j}=\left\{\begin{array}{cl}
f\left(d\left(v_{i}\right), d\left(v_{)}\right)\right. & \text {if } v_{i} v_{j} \in \mathbf{E}(G) \\
0 & \text { if } v_{i} v_{j} \notin \mathbf{E}(G) \\
0 & \text { if } i=j
\end{array}\right.
$$


If its eigenvalues are $\mu_{1}, \mu_{2}, \ldots, \mu_{n}$, then the energy pertaining to the VDB invariant $\mathcal{I}$, Eq. (3), is

$$
\mathcal{E}_{\mathcal{I}}=\mathcal{E}_{\mathcal{I}}(G)=\sum_{i=1}^{n}\left|\mu_{i}\right| .
$$

For recent works on the investigation of this class of graph-spectral invariants see (Das et al, 2018; Gutman, 2020, 2021; Gutman et al, 2022, 2021; Li \& Wang, 2021; Shao et al, 2021).

\section{Main results}

A cycle of length $p$ is a cycle consisting of (exactly) $p$ vertices $v_{1}, v_{2}, \ldots, v_{p}$, so that $v_{i}$ and $v_{i+1}$ are adjacent for $i=1,2, \ldots, p-1$, and also $v_{1}$ and $v_{p}$ are adjacent. As it is well known, a graph $G$ is bipartite if and only if all its cycles (if any) are of even length. In this paper, we prove the results valid for bipartite graphs which do not possess cycles of a length divisible by 4 . Let $G$ be such a graph. Without loss of generality, we assume that $G$ is connected.

Let the graph energy $\mathcal{E}$ and the VDB energy $\mathcal{E}_{\mathcal{I}}$ be the quantities defined via Eqs. (2) and (5), and let $f$ be the function specified in Eq. (3). Let $\delta$ ad $\Delta$ be the smallest and largest vertex degrees of $G$.

THEOREM 1. Let $G$ be a bipartite graph with no cycle of size divisible by 4 . Then

$$
f(\delta, \delta) \mathcal{E}(G) \leq \mathcal{E}_{\mathcal{I}}(G) \leq f(\Delta, \Delta) \mathcal{E}(G)
$$

holds for all $V D B$ invariants in which the function $f$ is monotonically increasing and $f(x, y) \geq 1$ for all vertex degrees $x$ and $y$. Equality on both sides holds if and only if $G$ is a regular graph, in which case $\delta=\Delta$.

The examples of the VDB invariants for Theorem 1 are the above listed first and second Zagreb, forgotten, Sombor, and nirmala indices.

THEOREM 2. Let $G$ be a bipartite graph with no cycle of size divisible by 4 . Then

$$
f(\Delta, \Delta) \mathcal{E}(G) \leq \mathcal{E}_{\mathcal{I}}(G) \leq f(\delta, \delta) \mathcal{E}(G)
$$

holds for all $V D B$ invariants in which the function $f$ is monotonically decreasing and $0<f(x, y) \leq 1$ for all vertex degrees $x$ and $y$. Equality on both sides holds if and only if $G$ is a regular graph. 
The examples of the VDB invariants for Theorem 2 are the above listed Randić, sum-connectivity, harmonic, and modified Sombor indices, as well as the inverse degree.

A tree is a connected graph with no cycles. Therefore, Theorems 1 and 2 apply to trees. For any tree $\delta=1$, but Theorems 1 and 2 can be slightly strengthened.

THEOREM 3. Let $T$ be a tree with $n \geq 3$ vertices. Then

$$
f(1,2) \mathcal{E}(T) \leq \mathcal{E}_{\mathcal{I}}(T)<f(\Delta, \Delta) \mathcal{E}(T)
$$

holds for all $V D B$ invariants in which the function $f$ is monotonically increasing and $f(x, y) \geq 1$ for all $x, y$. Equality on the left-hand side holds if and only if $n=3$.

THEOREM 4. Let $T$ be a tree with $n \geq 3$ vertices. Then

$$
f(\Delta, \Delta) \mathcal{E}(T)<\mathcal{E}_{\mathcal{I}}(T) \leq f(1,2) \mathcal{E}(T)
$$

holds for all $V D B$ invariants in which the function $f$ is monotonically decreasing and $0<f(x, y) \leq 1$ for all $x, y$. Equality on the right-hand side holds if and only if $n=3$.

In addition to trees, Theorems 1 and 2 are applicable to various classes of cycle-containing graphs. Of these, of particular interest may be the hexagonal systems (molecular graphs of benzenoid hydrocarbons) (Gutman \& Cyvin, 1989). All their vertices are of degrees 2 and 3 . The so-called catacondesned hexagonal systems (= hexagonal systems having no internal vertices) are known to possess only cycles of size $4 p+2$. For these molecular graphs

$$
f(2,2) \mathcal{E}(G)<\mathcal{E}_{\mathcal{I}}(G)<f(3,3) \mathcal{E}(G) .
$$

or

$$
f(3,3) \mathcal{E}(G)<\mathcal{E}_{\mathcal{I}}(G)<f(2,2) \mathcal{E}(G) .
$$

depending on whether $f(x, y)$ monotonically increases or decreases.

Hexagonal systems possessing internal vertices have cycles of size $4 p, p=3,4, \ldots$, and thus Theorems 1 and 2 are not applicable. We nevertheless conjecture that estimates (6) and (7) are valid for all hexagonal systems. 
In order to prove the above theorems, we need an auxiliary result, stated below as Lemma 3.

\section{Energy of a weighted bipartite graph}

The main part of the results outlined in this section was reported in (Gutman et al, 2021). These are repeated here (in an abbreviated form) in order to maintain completeness. Also, a few errors committed in (Gutman et al, 2021) are corrected.

Let $G$ be a bipartite graph with $n$ vertices. Let $G_{w}$ be obtained from $G$ by associating weighs to its edges, so that $w_{i j}$ is the weight of the edge $i j$. Then the characteristic polynomial of $G_{w}$ is of the form (Cvetković et al, 2010)

$$
\phi\left(G_{w}, \lambda\right)=\lambda^{n}+\sum_{k \geq 1}(-1)^{k} c\left(G_{w}, k\right) \lambda^{n-2 k}
$$

whereas the energy of $G_{w}$ satisfies the equality (Gutman, 1977, 2020; Li et al, 2012)

$$
\mathcal{E}\left(G_{w}\right)=\frac{2}{\pi} \int_{0}^{+\infty} \frac{d x}{x^{2}} \ln \left[1+\sum_{k \geq 1} c\left(G_{w}, k\right) x^{2 k}\right] .
$$

Note that $\mathcal{E}\left(G_{w}\right)$ is a monotonically increasing function of any of the coefficients $c\left(G_{w}, k\right)$.

According to the Sachs theorem (Cvetković et al, 2010)

$$
(-1)^{k} c\left(G_{w}, k\right)=\sum_{\sigma \in \mathcal{S}_{2 k}\left(G_{w}\right)}(-1)^{p(\sigma)} 2^{c(\sigma)} w(\sigma)
$$

where $\mathcal{S}_{k}\left(G_{w}\right)$ is the set of all Sachs graphs of $G_{w}$ possessing exactly $2 k$ vertices, and where $\sigma$ is an element of $\mathcal{S}_{2 k}\left(G_{w}\right)$, containing $p(\sigma)$ components, of which $c(\sigma)$ are cycles. The weight of the Sachs graph $\sigma$ is equal to the product of the weights of its components. If the isolated edge $i j$ is a component of $\sigma$, then its weight is $w_{i j}^{2}$. If a cycle $Z$ is a component of $\sigma$, then its weight is the product of weights of the edges contained in $Z$.

LemmA 1. (Gutman et al, 2021) If the Sachs graph $\sigma \in \mathcal{S}_{2 k}\left(G_{w}\right) \neq \emptyset$ does not contain cycles whose size is divisible by 4 , then

$$
(-1)^{k}(-1)^{p(\sigma)} 2^{c(\sigma)}>0 \text {. }
$$


Proof. The Sachs graph $\sigma$ has $p(\sigma)$ components. Let among them be $r_{0} \geq$ 0 isolated edges, whose total number of vertices is $2 r_{0}$. Let $\sigma$ contain $r_{1} \geq 0$ cycles, whose total number of vertices is $4 x+2 r_{1}$ for some integer $x$. Thus, $2 k=2 r_{0}+4 x+2 r_{1}$.

Case 1: $2 k$ is not divisible by 4 . Then $(-1)^{k}=-1$ whereas $r_{0}+r_{1}=p(\sigma)$ is odd. Therefore, $(-1)^{k}(-1)^{p(\sigma)}>0$ and the claim of Lemma 1 holds.

Case 2: $2 k$ is divisible by 4 . Then $(-1)^{k}=+1$ whereas $r_{0}+r_{1}=p(\sigma)$ is even, implying, again, $(-1)^{k}(-1)^{p(\sigma)}>0$.

Lemma 1 has the following noteworthy consequences:

\section{LEMMA 2.}

(a) Let $G_{w}$ be an edge-weighted bipartite graph whose all cycles (if any) have size not divisible by 4 , and let the weights of all its edges be positivevalued. Then for any Sachs graph $\sigma \in \mathcal{S}_{2 k}\left(G_{w}\right) \neq \emptyset$,

$$
(-1)^{k}(-1)^{p(\sigma)} 2^{c(\sigma)} w(\sigma)>0 .
$$

(b) Therefore, because of Eq. (10), the coefficients $c\left(G_{w}, k\right)$ in Eq. (8) are non-negative and are the monotonically increasing functions of the edgeweights.

(c) Therefore, because of Eq. (9), the energy of the graphs $G_{w}$ is a monotonically increasing function of the edge-weights.

From Lemma 2(c), we obtain the result needed for our proofs:

LemmA 3. Let $G_{w}$ be an edge-weighted bipartite graph whose all cycles (if any) have size not divisible by 4.

(a) If for all edges ij $\in \mathbf{E}\left(G_{w}\right)$, the condition $w_{i j} \geq 1$ holds, then $\mathcal{E}\left(G_{w}\right) \geq$ $\mathcal{E}(G)$. If $w_{i j}>1$ for at least one edge $i j$, then $\mathcal{E}\left(G_{w}\right)>\mathcal{E}(G)$.

(b) If for all edges ij $\in \mathbf{E}\left(G_{w}\right)$, the condition $w_{i j} \leq 1$ holds, then $\mathcal{E}\left(G_{w}\right) \leq$ $\mathcal{E}(G)$. If $w_{i j}<1$ for at least one edge $i j$, then $\mathcal{E}\left(G_{w}\right)<\mathcal{E}(G)$.

(c) If in both cases (a) and (b), $w_{i j}=w$ holds for all edges $i j \in \mathbf{E}\left(G_{w}\right)$, then $\mathcal{E}\left(G_{w}\right)=w \mathcal{E}(G)$.

\section{Proof of Theorems 1-4}

The adjacency matrix $\mathbf{A}_{\mathcal{I}}(G)$, Eq. (4), could be viewed as the ordinary adjacency matrix of an edge-weighted modification of the graph $G$. Therefore, if the condition $f\left(d_{v_{i}}, d_{v_{j}}\right)>1$ holds, and if $f(x, y)$ is an increasing 
function for $x \geq 1$ and $y \geq 1$, then the lower bound of Theorem 1 follows by Lemma 3 if all $f(x, y)$ are replaced by $f(\delta, \delta)$. The upper bound is obtained if all $f(x, y)$ are replaced by $f(\Delta, \Delta)$.

The proof of Theorem 2 is analogous.

Theorems 3 and 4 are based on the fact that no tree with $n \geq 3$ vertices is a regular graph. The only tree having two adjacent degree-one vertices is the two-vertex tree. Therefore, for trees with 3 or more vertices, the minimal (resp. maximal) value of $f(x, y)$ is $f(1,2)$.

\section{References}

Cvetković, D., Rowlinson, P. \& Simić, K. 2010. An Introduction to the Theory of Graph Spectra. Cambridge: Cambridge University Press. ISBN: 9780521134088.

Das, K.C., Gutman, I., Milovanović, I., Milovanović, E. \& Furtula, B. 2018. Degree-based energies of graphs. Linear Algebra and its Applications, 554, pp.185-204. Available at: https://doi.org/10.1016/j.laa.2018.05.027.

Gutman, I. 1977. Acyclic systems with extremal Hückel $\pi$-electron energy. Theoretica chimica acta, 45, pp.79-87. Available at: https://doi.org/10.1007/BF00552542.

Gutman, I. 2020. Relating graph energy with vertex-degree-based energies. Vojnotehnički glasnik/Military Technical Courier, 68(4), pp.715-725. Available at: https://doi.org/10.5937/vojtehg68-28083.

Gutman, I. 2021. Comparing degree-based energies of trees. Contributions to Mathematics, 4, pp.1-5. Available at: https://doi.org/10.47443/cm.2021.0030.

Gutman, I. \& Cyvin, S.J. 1989. Introduction to the theory of benzenoid hydrocarbons. Berlin: Springer. Available at: https://doi.org/10.5860/choice.27-4521.

Gutman, I., Monsalve, J. \& Rada, J. 2022. A relation between a vertexdegree-based topological index and its energy. Linear Algebra and its Applications, 636(March), pp.134-142. Available at: https://doi.org/10.1016/j.laa.2021.11.021.

Gutman, I., Redžepović, I. \& Rada, J. 2021. Relating energy and Sombor energy. Contributions to Mathematics, 4, pp.41-44. Available at:

https://doi.org/10.47443/cm.2021.0054.

Kulli, V.R. 2020. Graph indices. In: Pal, M., Samanta, S. \& Pal, A. (Eds.), Handbook of Research of Advanced Applications of Graph Theory in Modern Society, pp.66-91. Hershey, USA: IGI Global. Available at: https://doi.org/10.4018/978-1-5225-9380-5.ch003.

Li, X., Shi, Y. \& Gutman, I. 2012. Introduction. In: Graph Energy, pp.1-9. New York, NY: Springer. Available at: https://doi.org/10.1007/978-1-4614-4220-2_1. 
Li, X. \& Wang, Z. 2021. Trees with extremal spectral radius of weighted adjacency matrices among trees weighted by degree-based indices. Linear Algebra and Its Applications, 620, pp.61-75. Available at:

https://doi.org/10.1016/j.laa.2021.02.023.

Ramane, H.S. 2020. Energy of graphs. In: Pal, M., Samanta, S., \& Pal, A. (Eds.) Handbook of Research on Advanced Applications of Graph Theory in Modern Society, pp.267-296. Hershey, PA, USA: IGI Global. Available at: https://doi.org/10.4018/978-1-5225-9380-5.ch011.

Shao, Y., Gao, Y., Gao, W. \& Zhao, X. 2021. Degree-based energies of trees. Linear Algebra and Its Applications, 621, pp.18-28. Available at: https://doi.org/10.1016/j.laa.2021.03.009.

Todeschini, R. \& Consonni, V. 2009. Molecular Descriptors for Chemoinformatics. Weinheim: Wiley-VCH. ISBN: 978-3-527-31852-0.

\section{ОЦЕНКА ЭНЕРГИЙ, ОНСОВАННЫХ НА СТЕПЕНИ} ВЕРШИН

Иван Гутман

Крагуевацкий университет, естественно-математический факультет, г. Крагуевац, Республика Сербия

РУБРИКА ГРНТИ: 27.00.00 МАТЕМАТИКА:

27.29.19 Краевые задачи и задачи на собственные значения для обыкновенных диффференциальных уравнений и систем уравнений

ВИД СТАТЬИ: оригинальная научная статья

\section{Резюме:}

Введение / цель: В новейшей литературе изучаются десятки инвариантов графов, основанных на степени вершин (VDB). К каждому такому инварианту может присоединиться матрица. Энергия VDB - это энергия (= сумма абсолютных значений собственных значений) соответствующей матрицы VDB. В данной статье исследуются некоторые общие свойства VDB-энергии двудольных графов.

Результаты: Получены оценки (нижней и верхней границы) по энергии VDB двудольных графов, не имеющих циклов величины, кратной 4, в зависимости от обычной энергии графpa. 
Выводы: Результаты статьи вносят вклад в спектральную теорию матрии VDB, а особенно в общую теорию энергии VDB.

Ключевые слова: инвариант графра основанный на степени вершины, матрица основанная на степени вершины, энергия основанная на степени вершины, энергия (графра).

\section{ПРОЦЕНА ЕНЕРГИЈА ЗАСНОВАНИХ НА СТЕПЕНИМА ЧВОРОВА}

Иван Гутман

Универзитет у Крагујевцу, Природно-математички фракултет, Крагујевац, Република Србија

ОБЛАСТ: математика

ВРСТА ЧЛАНКА: оригинални научни рад

Сажетак:

Увод/циљ: У новијој литератури проучавају се бројне графовске инваријанте засноване на степенима чворова (VDB). Свакој од ових инваријанти може се придружити матрица. VDB енергија је енергија (= збир апсолутних вредности сопствених вредности) одговарајуће VDB матрице. Рад истражује неке опште особине VDB енергије бипартитних графова.

Резултати: Добијене су процене (доње и горње границе) за VDB енергију бипартитних графова који немају циколве величине дељиве са 4, а у зависности од обичне графовске енергије.

Закључак: Резултати овог рада доприносе спектралној mеорији VDM матрица, а посебно опитој теорији VDB енергије.

Кључне речи: инваријанта заснована на степенима чворова, матрица заснована на степенима чворова, енергија заснована на степенима чворова, енергија (графра).

Paper received on / Дата получения работы / Датум пријема чланка: 27.12.2021. Manuscript corrections submitted on / Дата получения исправленной версии работы / Датум достављања исправки рукописа: 04.01.2022.

Paper accepted for publishing on / Дата окончательного согласования работы / Датум коначног прихватања чланка за објављивање: 05.01.2022. 
(C) 2022 The Authors. Published by Vojnotehnički glasnik / Military Technical Courier (http://vtg.mod.gov.rs, http://втг.мо.упр.срб). This article is an open access article distributed under the terms and conditions of the Creative Commons Attribution license (http://creativecommons.org/licenses/by/3.0/rs/).

(c) 2022 Авторы. Опубликовано в "Военно-технический вестник / Vojnotehnički glasnik / Military Technical Courier" (http://vtg.mod.gov.rs, http://втг.мо.упр.срб). Данная статья в открытом доступе и распространяется в соответствии с лицензией "Creative Commons" (http://creativecommons.org/licenses/by/3.0/rs/).

(c) 2022 Аутори. Објавио Војнотехнички гласник / Vojnotehnički glasnik / Military Technical Courier (http://vtg.mod.gov.rs, http://втг.мо.упр.срб). Ово је чланак отвореног приступа и дистрибуира се у складу са Creative Commons лиценцом (http://creativecommons.org/licenses/by/3.0/rs/).

\section{(c) (7)}

